\title{
IDENTIFIKASI KEGAGALAN, ALTERNATIF PERBAIKAN DAN PERKUATAN PADA STRUKTUR GEDUNG POLTEKES SITEBA PADANG
}

\author{
Febrin Anas Ismail ${ }^{1}$
}

\begin{abstract}
ABSTRAK
Pasca gempa 30 September 2009 Gedung Poltekes mengalami kerusakan yang cukup parah, baik kerusakan struktural maupun kerusakan non-struktural. Berdasarkan hasil investigasi lapangan, diketahui bahwa kerusakan tersebut disebabkan oleh penggunaan mutu beton yang tidak memenuhi syarat serta penulangan geser yang berdiameter kecil dengan jarak pemasangan yang tidak sesuai standar. Kerusakan ini terjadi sebagian pada kolom dengan kegagalan berupa keruntuhan geser. Investigasi terhadap potensi likuifaksi juga dilakukan disekitar gedung Poltekes karena disekitar gedung Poltekes Siteba Padang memiliki potensi likuifaksi. Akan tetapi dari hasil analisa diketahui bahwa likuifaksi ternyata tidak terjadi pada gedung ini. Hasil perhitungan ulang yang dilakukan dengan program SAP 2000 mengindikasikan bahwa keruntuhan yang terjadi disebabkan oleh besarnya gaya geser, sementara tulangan yang terpasang tidak mampu memikul beban yang bekerja. Berdasarkan analisa tersebut maka diberikan alternatif perbaikan dan perkuatan untuk gedung Poltekes Siteba Padang. Perbaikan dilakukan dengan mengganti mutu beton serta menambah tulangan geser. Perkuatan dilakukan dengan metoda jacketing dan dinding geser. Setelah dianalisa ulang, metoda perbaikan ternyata dapat meningkatkan kapasitas penampang kolom sebesar $48 \%$ dibandingkan kondisi awal dengan perkuatan berupa dinding geser, kapasitas penampang kolom naik sebesar 32\% dibandingkan dengan kapasitas kondisi eksisting. Sementara metode jacketing (Boen, 2009) meningkatkan kapasitas yang paling besar hingga lebih dari dua kali lipat kapasitas kolom sebelum diperkuat.
\end{abstract}

Kata Kunci: kegagalan struktur, likuifaksi, perbaikan, perkuatan, jacketing, dinding geser.

\section{PENDAHULUAN}

Gempa bisa diakibatkan oleh pergeseran tiba-tiba dari lapisan tanah di bawah permukaan bumi. Ketika pergeseran ini terjadi, timbul getaran yang disebut gelombang seismik gempa ke segala arah di dalam bumi. Sumatera Barat adalah salah satu daerah yang rawan gempa karena berdekatan dengan pertemuan dua lempeng Hindia dan Asia pada pesisir pantainya serta dilalui oleh sesar semangko. Tercatat sejak tahun 2004 setelah terjadinya gempa besar dan tsunami di Aceh, di Sumatera Barat sering terjadi gempa dan yang terparah terjadi pada 6 Maret 2007 dengan kekuatan 6.3 SR. Gempa ini dapat dirasakan sampai ke Singapura dan Malaysia dan pada 30 September 2009 dengan kekuatan 7.9 SR yang telah menyebabkan kerusakan parah di beberapa wilayah di Sumatera Barat. Kota Padang merupakan daerah yang mengalami kerusakan cukup parah dan kerugian materil yang besar pada gempa 30 Septemer 2009. Banyak gedung-gedung pemerintahan, fasilitas umum dan sekolah yang mengalami kerusakan. Salah satunya adalah gedung Poltekes Siteba Padang.

Tujuan dari Penulisan makalah tentang Identifikasi Kegagalan, Alternatif Perbaikan dan Perkuatan pada Struktur Bangunan Poltekes Siteba Padang ini adalah :

1. Mengidentifikasi penyebab dan jenis kegagalan struktur yang terjadi pada gedung Poltekes Siteba Padang.

2. Menghitung kembali kapasitas gedung Poltekes Siteba Padang

${ }^{1}$ Dosen Jurusan Teknik Sipil Universitas Andalas, febrin@ft.unand.ac.id 
3. Memberikan alternatif metoda yang tepat untuk perbaikan dan perkuatan gedung ini.

Manfaat penulisan ini adalah agar dapat digunakan sebagai bahan referensi untuk mengetahui penyebab kerusakan bangunan dan cara perbaikan serta perkuatan dari kerusakan yang disebabkan oleh gempa.

\section{PEMBAHASAN}

\subsection{Kerusakan Struktural Bangunan}

Kerusakan yang dominan pada bangunan ini adalah kerusakan pada elemen struktural bangunan. Elemen struktur kolom merupakan bagian yang mengalami kerusakan berat, lebih dari 80\% kolom bangunan mengalami kerusakan. Kerusakan yang terjadi berupa hancurnya beton kolom bangunan tersebut. Kerusakan pada kolom di masing-masing lantai dapat dilihat pada Gambar 1 - 3.
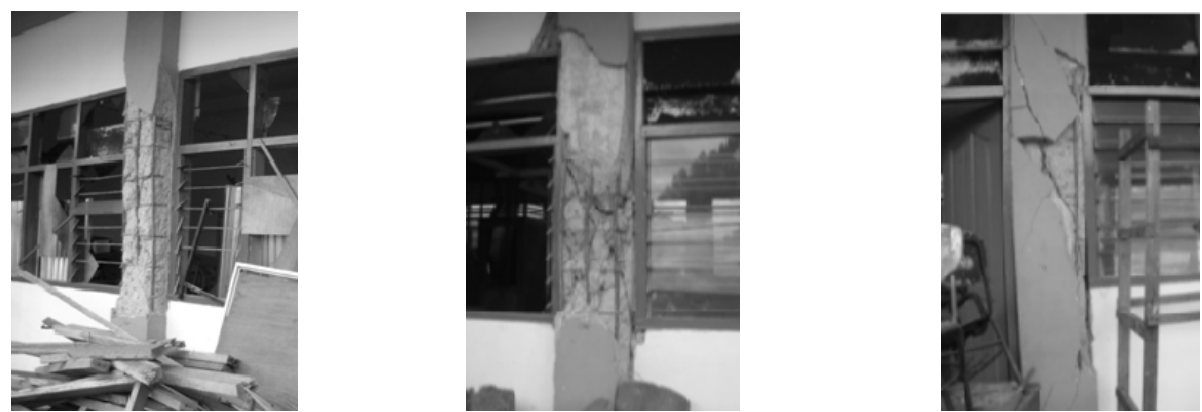

Gambar 1. Kerusakan Kolom Pada Lantai 1
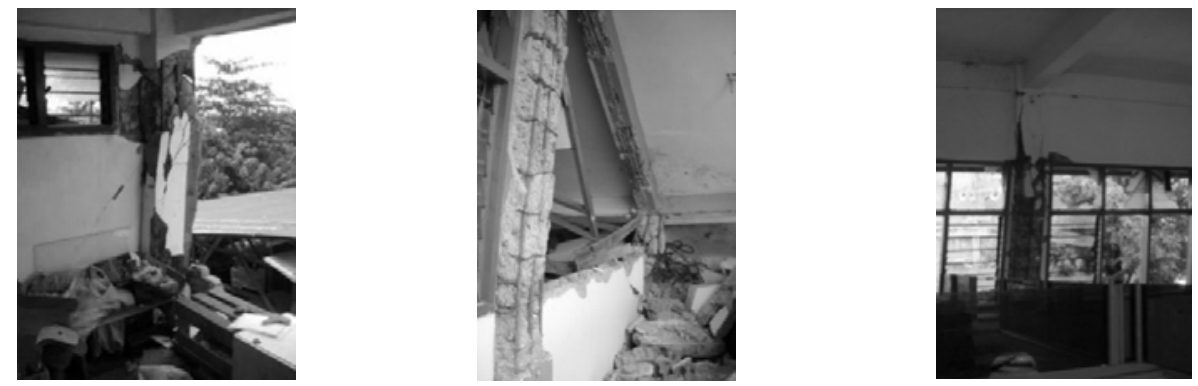

Gambar 2. Kerusakan Pada Kolom Lantai 2
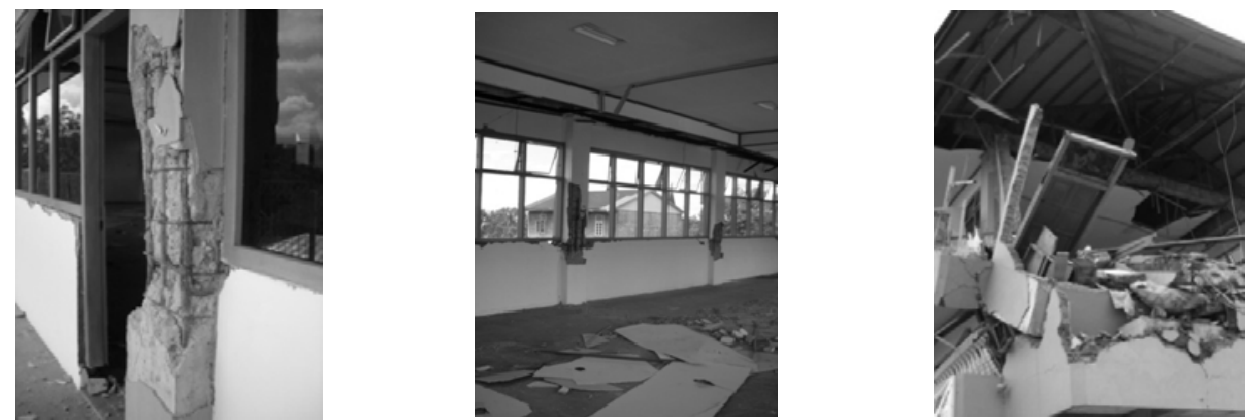

Gambar 3. Kerusakan Pada Kolom dan Pelat Lantai 3

\section{2 | JURNAL REKAYASA SIPIL}




\subsection{Idealisasi Struktur}

Idealisasi struktur gedung Poltekes Siteba Padang yang akan dianalisis adalah penyebab keruntuhan dan kinerja struktur gedungnya pada penelitian ini sama dengan yang direncanakan pada tahap perencanaan yaitu struktur beton bertulang 3 tingkat 3 dimensi (Gambar 4.)

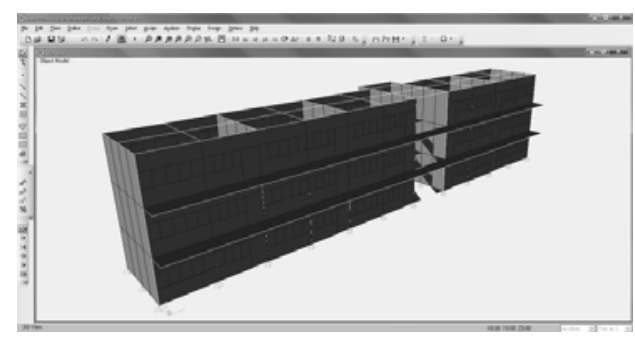

Gambar 4. Idealisasi Struktur dengan SAP 2000

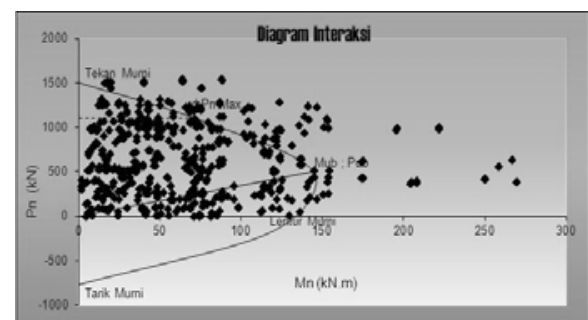

Gambar 5. Diagram Interaksi kolom K1 (40 x 40)

Kapasitas penampang kolom diketahui dari diagram interaksi masing-masing penampang kolom. Gambar 5. merupakan diagram interaksi kolom K1 ukuran $40 \mathrm{~cm}$ x $40 \mathrm{~cm}$.

Tabel 1. Kapasitas Daya Dukung Kolom Eksisting

\begin{tabular}{|c|c|c|c|c|c|c|c|c|c|}
\hline \multirow{2}{*}{ No } & \multirow{2}{*}{ Kode } & \multicolumn{2}{|c|}{ Dimensi } & \multirow{3}{*}{$\begin{array}{l}\text { Geser } \\
\text { Maks } \\
\end{array}$} & \multirow{2}{*}{\multicolumn{2}{|c|}{ Tulangan geser }} & \multirow{2}{*}{\multicolumn{2}{|c|}{$\begin{array}{c}\text { Tulangan geser } \\
\text { terpasang }\end{array}$}} & \multirow{3}{*}{ Kode } \\
\hline & & Lebar & Tinggi & & & & & & \\
\hline & & & & & $\underset{(\mathbf{m m})}{\varnothing}$ & $\begin{array}{l}\text { Spasi } \\
\text { (cm) }\end{array}$ & $\begin{array}{c}\varnothing \\
(\mathbf{m m})\end{array}$ & $\begin{array}{l}\text { Spasi } \\
\text { (cm) }\end{array}$ & \\
\hline 1 & 1K14040 & 400 & 400 & 9.4429756 & 8 & 13 & 6 & 20 & not ok \\
\hline 2 & $1 \mathrm{~K} 24040$ & 400 & 400 & 4.10038 & 8 & 17.5 & 6 & 20 & not ok \\
\hline 3 & $1 \mathrm{~K} 34040$ & 400 & 400 & 9.7238372 & 8 & 11 & 6 & 20 & not ok \\
\hline 4 & 2K14040 & 400 & 400 & 6.4913973 & 8 & 17.5 & 6 & 20 & not ok \\
\hline 5 & 2K24040 & 400 & 400 & 3.938087 & 8 & 17.5 & 6 & 20 & not ok \\
\hline 6 & 2K34040 & 400 & 400 & 7.2783607 & 8 & 17.5 & 6 & 20 & not ok \\
\hline 7 & $3 \mathrm{~K} 14040$ & 400 & 400 & 2.4636522 & 8 & 17.5 & 6 & 20 & not ok \\
\hline 8 & $3 \mathrm{~K} 24040$ & 400 & 400 & 4.9129995 & 8 & 15 & 6 & 20 & not ok \\
\hline 9 & 3К34040 & 400 & 400 & 0.8742771 & 8 & 17.5 & 6 & 20 & not ok \\
\hline
\end{tabular}

Dari Tabel 1. terlihat bahwa kolom menerima gaya geser/gaya lateral yang cukup besar dan tulangan geser yang terpasang lebih kecil dari yang dibutuhkan, hal ini merupakan salah satu penyebab keretakan yang terjadi pasca gempa 2009. Nilai Simpangan Antar Tingkat Masa Gedung Akibat Gempa Arah - x dan y dapat dilihat pada Tabel 2 dan 3.

Tabel 2. Simpangan Antar Tingkat Masa Gedung Akibat Gempa Arah - x

\begin{tabular}{|c|c|c|c|c|c|c|}
\hline Level & Elevasi & Tinggi & $\begin{array}{c}\text { Simpangan } \\
\mathbf{x}\end{array}$ & $\begin{array}{c}\text { Simpangan } \\
\text { Antar Tingkat }\end{array}$ & $\begin{array}{c}\text { Rasio } \\
\text { Simpangan } \\
\text { Antar Tingkat }\end{array}$ & $\begin{array}{c}\text { Rasio Simpangan } \\
\text { Antar Tingkat } \\
\text { Maksimum }\end{array}$ \\
\hline atap & 12 & 4 & 0.000282 & 0.0000149 & 0.0000037 & 0.0086 \\
\hline 3 & 8 & 4 & 0.000267 & 0.000121 & 0.0000302 & 0.0086 \\
\hline 2 & 4 & 4 & 0.000146 & 0.000146 & 0.0000365 & 0.0086 \\
\hline 1 & 0 & 0 & 0 & 0 & 0 & 0.0086 \\
\hline
\end{tabular}


Tabel 3. Simpangan Antar Tingkat Massa Gedung Akibat Gempa Arah - y

\begin{tabular}{|c|c|c|c|c|c|c|}
\hline Level & Elevasi & Tinggi & $\begin{array}{c}\text { Simpangan } \\
\mathbf{y}\end{array}$ & $\begin{array}{c}\text { Simpangan } \\
\text { Antar Tingkat }\end{array}$ & $\begin{array}{c}\text { Rasio } \\
\text { Simpangan } \\
\text { Antar Tingkat }\end{array}$ & $\begin{array}{c}\text { Rasio Simpangan } \\
\text { Antar Tingkat } \\
\text { Maksimum }\end{array}$ \\
\hline atap & 12 & 4 & 0.0151 & 0.00546 & 0.001365 & 0.0086 \\
\hline 3 & 8 & 4 & 0.009636 & 0.004738 & 0.001185 & 0.0086 \\
\hline 2 & 4 & 4 & 0.004901 & 0.004901 & 0.001225 & 0.0086 \\
\hline 1 & 0 & 0 & 0 & 0 & 0 & 0.0086 \\
\hline
\end{tabular}

\subsection{Tegangan Geser Dinding}

Kemampuan dinding dalam menahan beban digambarkan oleh besarnya tegangan geser yang bekerja pada dinding, baik oleh beban lateral maupun beban akibat tekanan angin. Berdasarkan hasil perhitungan dengan SAP 2000, kombinasi pembebanan yang paling mendekati kondisi yang sebenarnya adalah kombinasi yang menggunakan $100 \%$ gempa arah y dan $30 \%$ gempa arah x. Pada gambar berikut terdapat bagian-bagian dari dinding bata yang mengalami tegangan geser akibat gempa melebihi tegangan geser bata yang diizinkan.

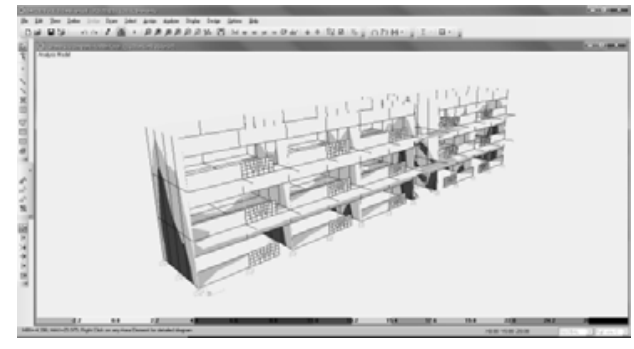

\section{Gambar 6. Tegangan Geser Dinding Gedung Poltekes Siteba Padang}

Gambar 6. diatas merupakan hasil dari analisa yang dilakukan dengan program SAP 2000. Dapat dilihat tegangan geser dinding yang melebihi nilai yang diizinkan banyak terdapat pada dinding arah sumbu y (sejajar bentang pendek bangunan). Tegangan geser izin adalah sebesar $2 \mathrm{~kg} / \mathrm{cm}^{2}$, sementara tegangan geser yang terjadi mencapai $\pm 4 \mathrm{~kg} / \mathrm{cm}^{2}$.

Tegangan geser dinding sejajar bentang pendek gedung Poltekes pada beberapa area/as bangunan dapat dilihat pada Gambar 7 - 9. Gambar 10 - 12. merupakan foto-foto kerusakan gedung yang terjadi, sebagai perbandingan hasil analisa menggunakan SAP 2000 dengan kerusakan yang terjadi dilapangan .
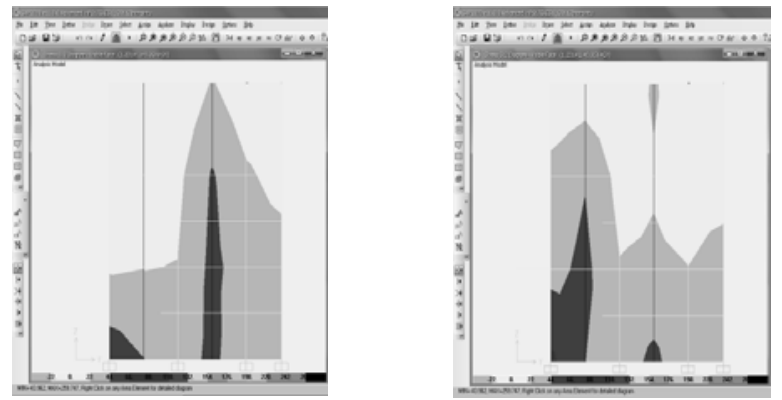

Gambar 7. Tegangan Geser Dinding Pada As-7 dan As-8 (dekat tangga)

\section{J URNAL REKAYASA SIPIL}




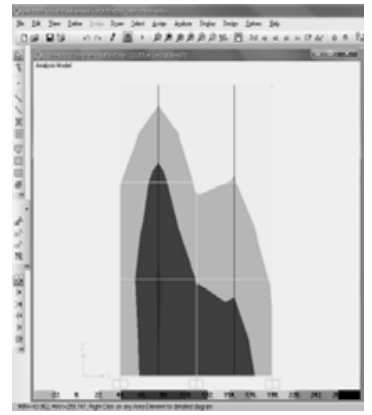

Gambar 8. Tegangan Geser Dinding Pada As-1

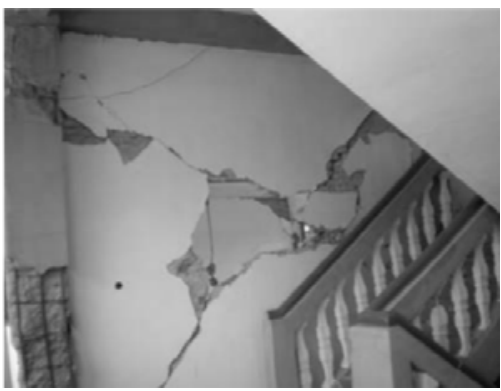

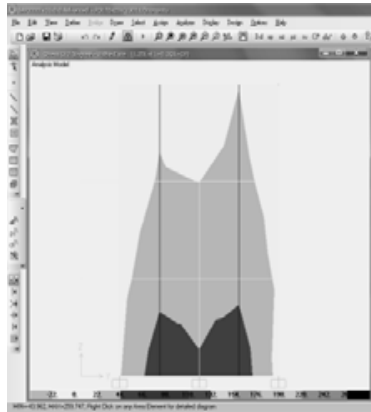

Gambar 9. Tegangan Geser Dinding Pada As-7

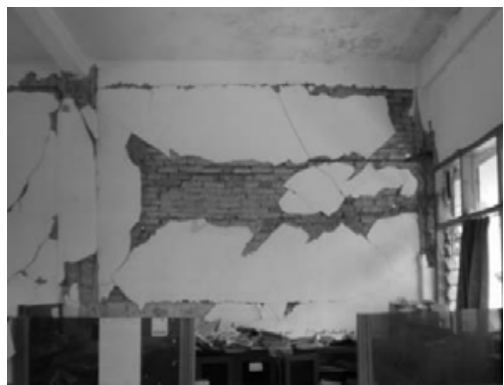

Gambar 10. Foto Kerusakan Gedung didekat Tangga Gambar 11. Foto Kerusakan Gedungpada As-1

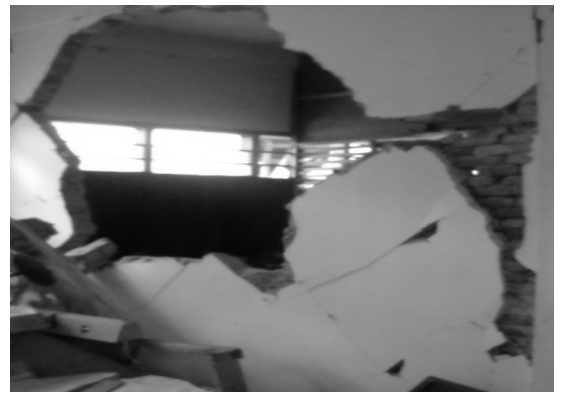

Gambar 12. Foto Kerusakan Gedung pada As-7

\subsection{Penyebab Kerusakan Struktur Gedung}

\subsubsection{Mutu Beton}

Rendahnya mutu beton yang digunakan pada gedung ini menjadi salah satu penyebab kerusakan pada struktur bangunan. Berdasarkan data yang diperoleh dari lapangan dengan melakukan hammer test, diperoleh mutu beton yang digunakan pada gedung ini hanya K-100 yang berada jauh dibawah standar mutu beton untuk bangunan gedung bertingkat. Terlihat dari semua kerusakan yang terjadi pada struktur diikuti dengan hancurnya beton.

\subsubsection{Tulangan Terpasang}

Pada penulangan lentur balok, terdapat beberapa ruas balok yang tidak memenuhi persyaratan dimana momen maksimum balok melebihi batas momen ultimit yang dapat ditanggung oleh penampang balok. Hal ini menjadi salah satu penyebab kerusakan yang terjadi. Pada penulangan 
kolom, dari diagram interaksi kolom menunjukkan banyak titik yang berada diluar garis interaksi P-M. Hal ini berarti tulangan lentur kolom yang terpasang tidak mampu memikul beban yang bekerja. Hal inilah yang menyebabkan ada beberapa kolom yang patah atau tulangan utamanya mengalami pembengkokan.

Demikian juga dengan tulangan geser pada kolom, dari hasil investigasi lapangan banyak kolom yang mempunyai sengkang dengan jarak yang sangat besar $(20 \mathrm{~cm})$ serta diameter tulangan yang terlalu kecil (Ø6). Hal ini tidak sesuai untuk struktur bangunan bertingkat tahan gempa. Dalam aturan untuk bangunan tahan gempa jarak sengkang minimum adalah $15 \mathrm{~cm}$ dan diameter tulangan geser yang digunakan adalah Ø10. Dan hal ini juga merupakan salah satu penyebab kegagalan pada gedung Poltekes Siteba sehingga gedung mudah mengalami kerusakan saat terjadi goncangan gempa.

\subsubsection{Kemiringan Gedung}

Dari hasil pengukuran kemiringan bangunan maka kemiringan yang terjadi pada gedung Poltekes Siteba Padang untuk arah vertikal maximum adalah 2,35 \% dan kemiringan arah horizontal maximum yang terjadi adalah $1,57 \%$. Walaupun sebagian kemiringan yang terjadi pada bangunan gedung Poltekes Siteba ini melebihi syarat kemiringan maksimum $(0,334 \%)$ tapi gedung ini masih dapat diperbaiki dan diperkuat.

\subsubsection{Potensi Likuifaksi}

Berdasarkan survey potensi likuifaksi yang telah dilakukan disekitar daerah gedung Poltekes, menunjukkan adanya potensi likuifaksi didaerah tersebut. Jenis tanah disekitar daerah tersebut merupakan tanah pasir lepas, yaitu jenis tanah yang memungkinkan terjadinya likuifaksi. Ketika mengalami getaran akibat gempa bumi, sifat tanah berubah menjadi seperti cairan yang mengakibatkan hilangnya kekuatan tanah sehingga tak mampu menopang beban bangunan di dalam atau di atasnya. Tanah yang menjadi lunak akan mengalami amplifikasi atau perbesaran guncangan terhadap gedung-gedung di atasnya. Peta potensi likuifaksi dapat dilihat pada Gambar 13.

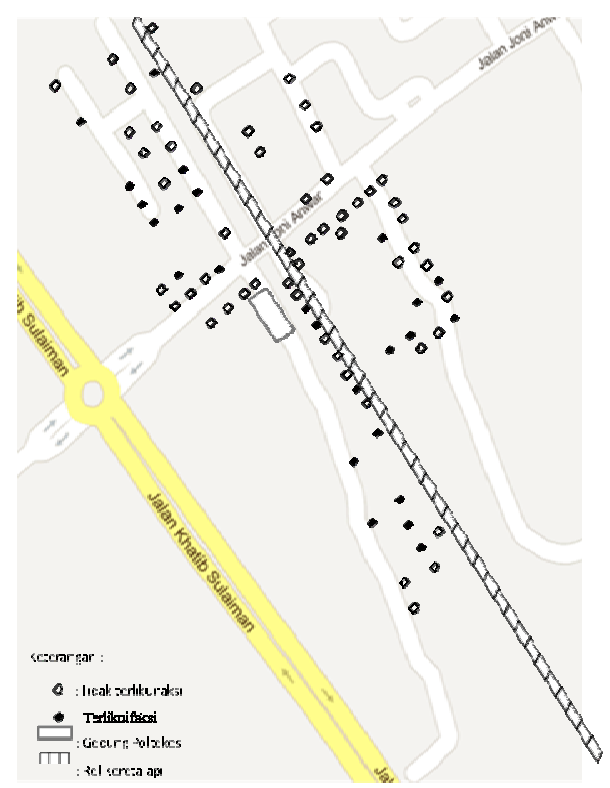

Gambar 13. Peta Potensi Likuifaksi di Daerah Sekitar Gedung Poltekes

\section{6 | J URNAL REKAYASA SIPIL}




\subsubsection{Konfigurasi bangunan}

Berdasarkan SNI-03-1726-2002, bangunan sebaiknya mempunyai denah yang sederhana, simetris dan berbentuk persegi panjang. Begitu juga dengan penampang bangunan tersebut. Bangunan yang sederhana menghasilkan respon gempa yang yang beraturan, sehingga mengurangi kemungkinan terjadinya konsentrasi gaya gempa hanya pada suatu bagian bangunan. Distribusi gaya gempa yang beraturan akan mengurangi resiko kerusakan bangunan akibat gempa. Rasio panjang bangunan terhadap lebarnya sebaiknya dibatasi kurang dari 3. Hal ini diperlukan untuk menghindari adanya ketimpangan sumbu kuat dan sumbu lemah pada suatu bangunan.

Jika denah bangunan tidak memenuhi ketentuan diatas, maka disarankan dilakukan pemisahan struktur bangunan tersebut (deletasi). Namun hal yang harus diingat adalah dilatasi harus mengakomodir simpangan maksimum struktur bangunan agar ketika terjadi gempa, kedua struktur tidak saling bertabrakan. SNI-03-1726-2002 pasal 8.2.3 dan 8.2.4 menetapkan dilatasi minimum adalah nilai maksimum dari 2,5\% tinggi total bangunan atau $75 \mathrm{~mm}$.

Dilihat dari denahnya, gedung Poltekes sudah memiliki denah yang sederhana karena berbentuk persegi panjang yang simetris dari lantai 1 sampai ke lantai 3. Namun dimensi bangunan Poltekes yaitu dengan panjang $50 \mathrm{~m}$ dan lebar hanya $7 \mathrm{~m}$, mengakibatkan adanya ketimpangan sumbu kuat dan sumbu lemah pada bangunan. Arah horizontal (panjang gedung) menjadi sumbu lemah, sehingga hal ini merupakan salah satu kelemahan yang dimiliki oleh gedung Poltekes.

\subsection{Perbaikan dan Perkuatan}

\subsubsection{Perbaikan}

Langkah perbaikan diambil menjadi salah satu alternatif perbaikan karena yang menjadi faktor utama penyebab kerusakan gedung adalah jeleknya mutu beton dan kecilnya diameter tulangan geser yang terpasang. Setelah mutu beton diganti dengan mutu K-250 dan tulangan geser diganti dengan diameter dan jarak yang memenuhi syarat untuk bangunan aman gempa (Ø10-150), kemudian dilakukan analisa ulang ternyata kekuatan struktur gedung cukup meningkat. Terlihat dari diagaram interaksi kolom pada Gambar 14., beban luar yang bekerja pada kolom berada didalam diagram interaksi P-M. Hal ini menunjukkan bahwa setelah diperkuat, kolom mampu memikul beban yang bekerja padanya.

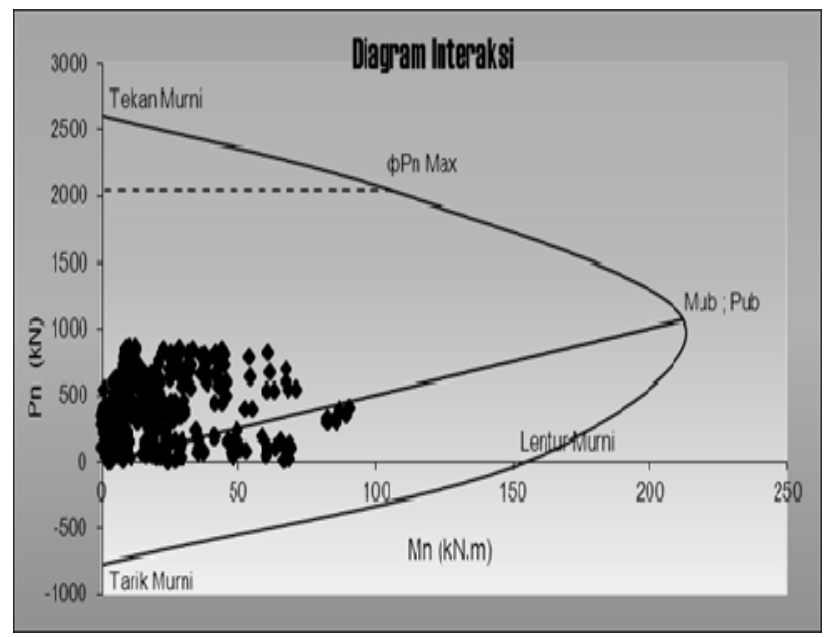

Gambar 14. Diagram Interaksi 1K14040 Kolom Setelah Perbaikan 


\subsubsection{Perkuatan dengan Jacketing}

Dengan metode ini, penampang kolom diperbesar dengan menambah tulangan lentur dan geser kolom di keliling kolom yang lama serta mengganti mutu beton yang lebih baik daripada mutu beton yang lama. Penampang kolom sebelum dan sesudah jacketing seperti pada Gambar 15.

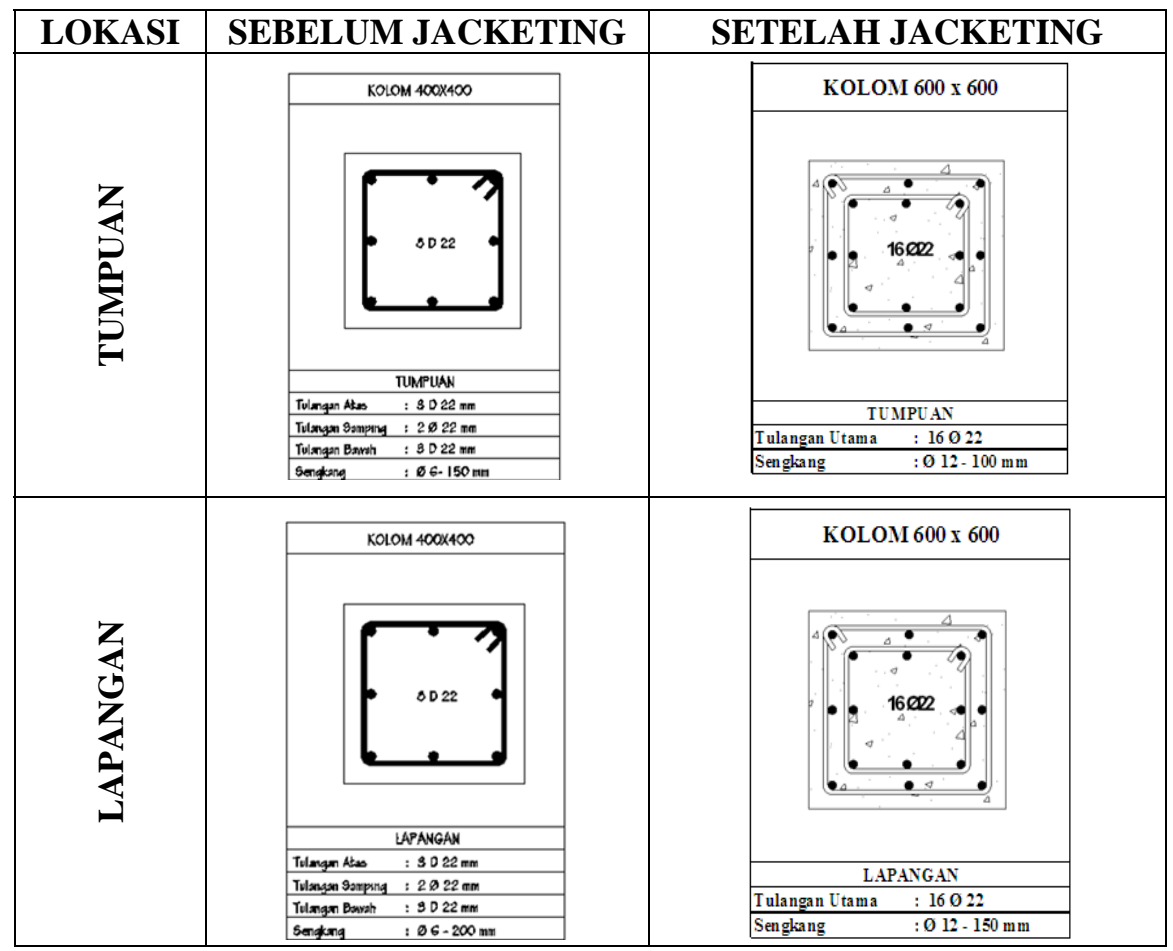

Gambar 15. Penampang Kolom Sebelum dan Sesudah Jacketing

\section{Perbandingan Momen Kolom, Sebelum dan Setelah Jacketing}

Dari diagram interaksi setelah jacketing pada Gambar 16. terlihat bahwa reftrofitting dengan jacketing akan meningkatkan kapasitas penampang kolom baik kapasitas lentur maupun aksialnya. Kapasitas lentur maupun aksial kolom sebelum perkuatan jauh lebih kecil dari beban aksial maupun lentur akibat beban yang bekerja pada kolom sehingga menyebabkan kegagalan struktur kolom saat gempa yang terjadi pada tanggal 30 September 2009. Dengan perbaikan dan perkuatan seperti yang direncanakan, kolom yang ada diharapkan memiliki kemampuan yang lebih baik dan mampu bertahan ketika terjadi gempa dengan intensitas yang sama dengan yang terjadi pada tanggal 30 September 2009.

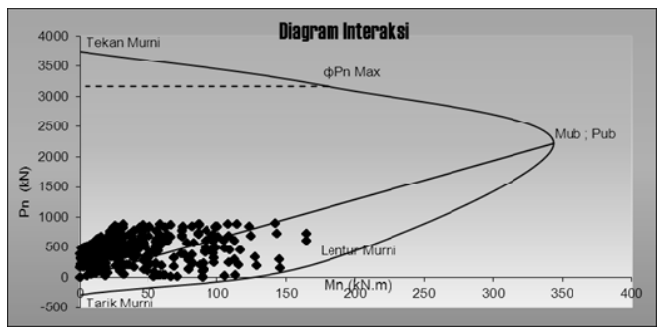

Gambar 16. Diagram Interaksi Kolom 1K14040 Setelah Jacketing

\section{8 | JURNAL REKAYASA SIPIL}




\section{Perbandingan Gaya Geser Kolom Eksisting dan Jacketing}

Tabel 4. Perbandingan Gaya Geser Kolom Sebelum dan Sesudah Jacketing

\begin{tabular}{|c|c|c|c|}
\hline No & Kode & $\begin{array}{c}\text { Gaya GeserSetelah } \\
\text { Retrofit }\end{array}$ & $\begin{array}{c}\text { Gaya } \\
\text { GeserSebelum } \\
\text { Retrofit }\end{array}$ \\
\hline 1 & $1 \mathrm{~K} 14040$ & 9.927882811 & 9.4429756 \\
2 & $1 \mathrm{~K} 24040$ & 6.477380656 & 4.10038 \\
3 & $1 \mathrm{~K} 34040$ & 9.538398407 & 9.7238372 \\
4 & $2 \mathrm{~K} 14040$ & 7.585284986 & 6.4913973 \\
5 & $2 \mathrm{~K} 24040$ & 4.310363563 & 3.938087 \\
6 & $2 \mathrm{~K} 34040$ & 8.421751617 & 7.2783607 \\
7 & $3 \mathrm{~K} 14040$ & 2.324398586 & 2.4636522 \\
8 & $3 \mathrm{~K} 24040$ & 5.574997974 & 4.9129995 \\
9 & $3 \mathrm{~K} 34040$ & 0.935246923 & 0.8742771 \\
\hline
\end{tabular}

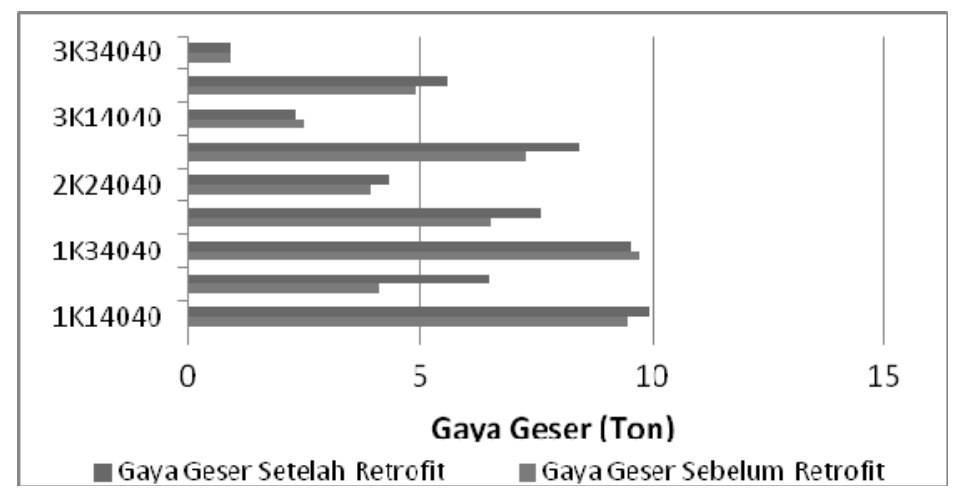

\section{Gambar 17. Grafik Perbandingan Gaya Geser Sebelum dan Sesudah Jacketing}

Dari Tabel 4. dan Gambar 17. terlihat bahwa secara umum gaya geser dengan metoda jacketing lebih besar daripada gaya geser sebelum jacketing, hanya pada kolom tertentu yang mempunyai gaya geser yang lebih kecil dari sebelumnya. Peningkatan gaya geser ini sekitar $10 \%$ dari gaya geser tanpa jacketing. Besarnya gaya geser yang terjadi setelah kolom dijacketing disebabkan oleh lebih besarnya kekakuan kolom dari sebelumnya, dengan peningkatan kekakuan kolom dari sebelumnya akan menghasilkan gaya geser yang lebih besar akibat gaya lateral. Seiring dengan peningkatan gaya geser kolom akibat peningkatan kekakuan, peningkatan kemapuan kolom dalam menahan gaya geser juga terjadi dan kemampuan kolom menahan gaya geser lebih besar dari gaya geser yang terjadi, sehingga retrofitting dengan jacketing ini dapat dijadikan salah satu alternatif perbaikan untuk kolom gedung Poltekes Siteba Padang.

\section{Perbandingan Simpangan Struktur Massa Lantai Sebelum dan Sesudah Jacketing}

Tabel 5. dan Gambar 18 - 19. memperlihatkan perbandingan perpindahan struktur sebelum dan setelah dilakukan jacketing. Simpangan sebelum dan sesudah perbaikan mempunyai pola yang sama, baik simpangan antar tingkat pada arah x maupun simpangan antar tingkat pada arah y. Dari hasil analisa diperoleh simpangan antar tingkat sesudah perbaikan lebih kecil dari simpangan antar tingkat sebelum perbaikan. Metoda jacketing dapat mereduksi perpindahan struktur hingga $46 \%$ dari perpindahan struktur gedung tanpa jacketing. Hal ini mengindikasikan bahwa kinerja struktur akan lebih baik setelah kolom diperbaiki dan diperbesar penampangnya. 
Tabel 5. Perbandingan Simpangan Antar Tingkat Sebelum dan Sesudah jacketing

\begin{tabular}{|c|c|c|c|c|c|c|}
\hline \multirow{2}{*}{ Level } & \multirow{2}{*}{ Elevasi } & \multirow{2}{*}{ Tinggi } & \multicolumn{2}{|c|}{ Simpangan Arah X } & \multicolumn{2}{c|}{ Simpangan Arah Y } \\
\cline { 4 - 7 } & & & $\begin{array}{c}\text { Sebelum } \\
\text { Perbaikan }\end{array}$ & $\begin{array}{c}\text { Setelah } \\
\text { Jacketing }\end{array}$ & $\begin{array}{c}\text { Sebelum } \\
\text { Perbaikan }\end{array}$ & Setelah Jacketing \\
\hline atap & 12 & 4 & 0.000282 & 0.000161914 & 0.0151 & 0.010425718 \\
\hline 3 & 8 & 4 & 0.000267 & 0.00014444 & 0.009636 & 0.006400742 \\
\hline 2 & 4 & 4 & 0.000146 & $6.95088 \mathrm{E}-05$ & 0.004901 & 0.002796513 \\
\hline 1 & 0 & 0 & 0 & 0 & 0 & 0 \\
\hline
\end{tabular}

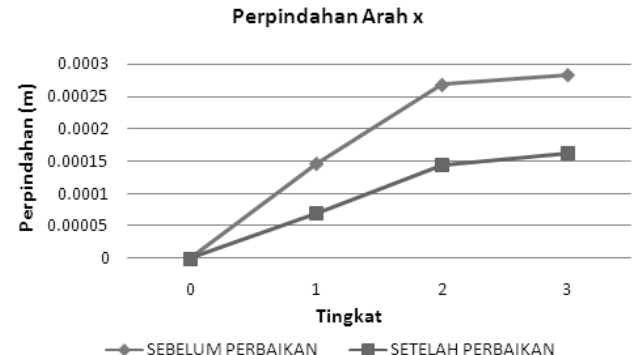

Gambar 18. Perbandingan Simpangan antar Tingkat Arah x Setelah jacketing

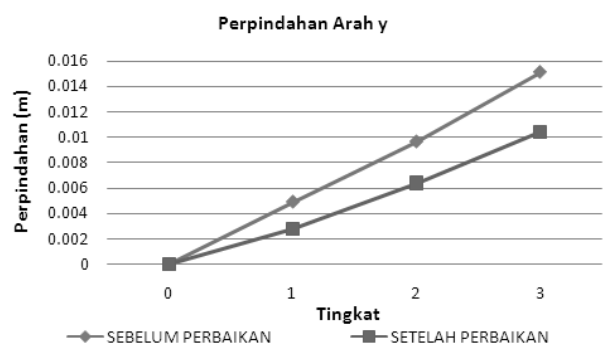

Gambar 19. Perbandingan Simpangan antar Tingkat Arah y Setelah jacketing

\subsubsection{Perkuatan dengan Dinding Geser}

Ada dua opsi yang dilakukan dalam penggunaan dinding geser ini, yaitu pertama di kedua ujung kolom pada As1 dan As12 arah vertikal, dan yang kedua di ujung kolom yang sama tetapi ditambah pada ujung kolom pada As A dan As C sehingga membentuk siku-siku, sebagaimana yang terlihat pada Gambar 20 - 21. Pada opsi pertama penggunaan dinding geser dapat meningkatkan kapasitas lentur kolom, seperti dapat dilihat pada diagram interaksi kolomnya. Tapi hal ini tidak didukung dengan kapasitas gesernya, dimana dengan gaya geser yang dihasilkan dari perkuatan dengan dinding geser masih belum mencukupi dengan tulangan yang terpasang.

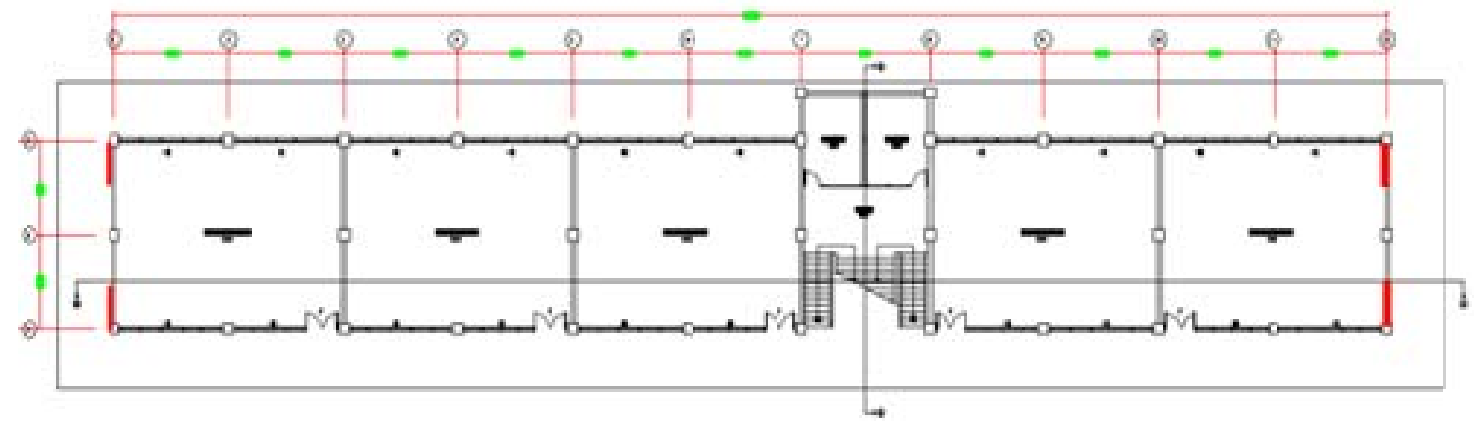

Ket : — dinding geser

Gambar 20. Posisi Dinding Geser Opsi Pertama 


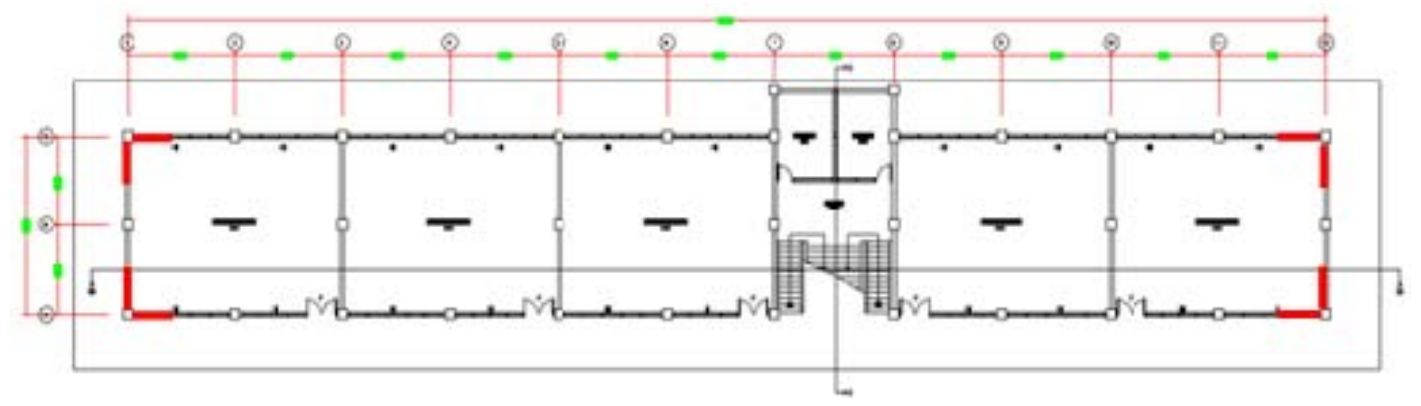

Ket : - dinding geser

\section{Gambar 21. Posisi Dinding Geser Opsi Kedua}

Pada opsi kedua diberikan tambahan dinding geser di sisi horizontal pada opsi yang pertama dengan harapan ditambahnya dinding geser maka kekakuan struktur akan meningkat sehingga tulangan yang terpasang akan mencukupi dan tidak perlumenambah penulangan yang telah ada. Namun dari hasil analisa, ternyata masih sama dengan opsi yang pertama. Untuk kapasitas lentur kolom sudah sangat memenuhi tetapi untuk kapasitas geser masih diperlukan penambahan tulangan.

Dari segi perpindahan, setelah diperkuat dengan dinding geser didapatkan perpindahan untuk arah $\mathrm{x}$ dan arah y jauh berkurang dibandingkan sebelum diberi perkuatan dengan dinding geser, seperti terlihat pada Gambar 22 - 25. Perpindahan yang terjadi hanya sekitar 2\% dari perpindahan sebelum diberi perkuatan. Dengan penggunaan dinding geser membuat kekakuan bangunan bertambah.

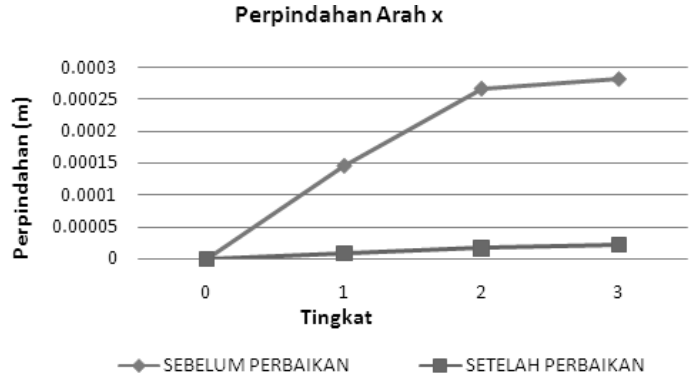

Gambar 22. Perbandingan simpangan antar tingkat arah $x$ pada perkuatandinding geser opsi1

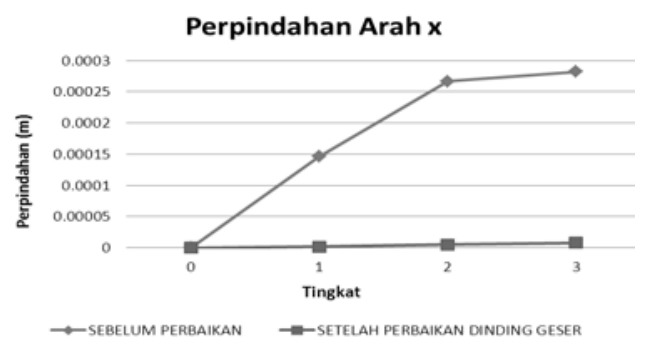

Gambar 24. Perbandingan simpangan antar tingkat arah $\mathrm{x}$ pada perkuatan dinding geser opsi 2

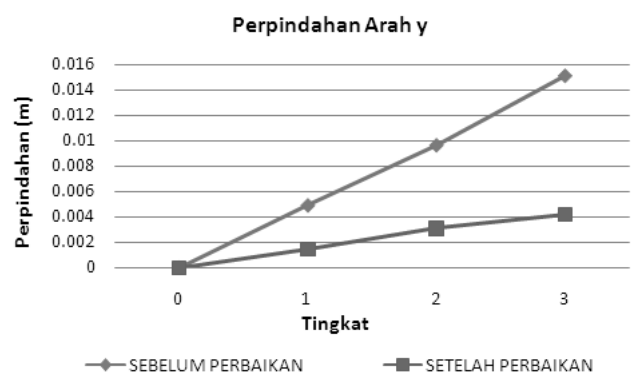

Gambar 23. Perbandingan simpangan antar tingkat arah y pada perkuatandinding geser opsi 1

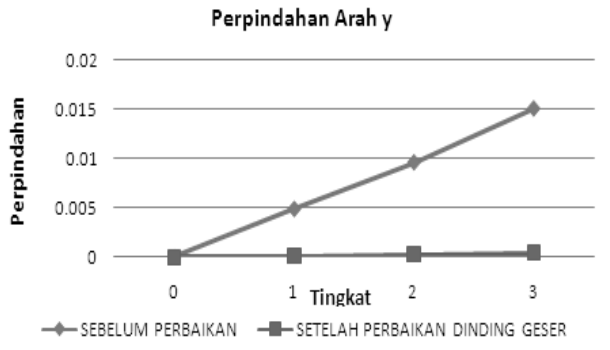

Gambar 25. Perbandingan simpangan antar tingkat arah y pada perkuatan dinding geser opsi 2 


\subsubsection{Perbandingan Kapasitas Penampang Kolom antara Kondisi Eksisting dengan Perbaikan dan Perkuatan}

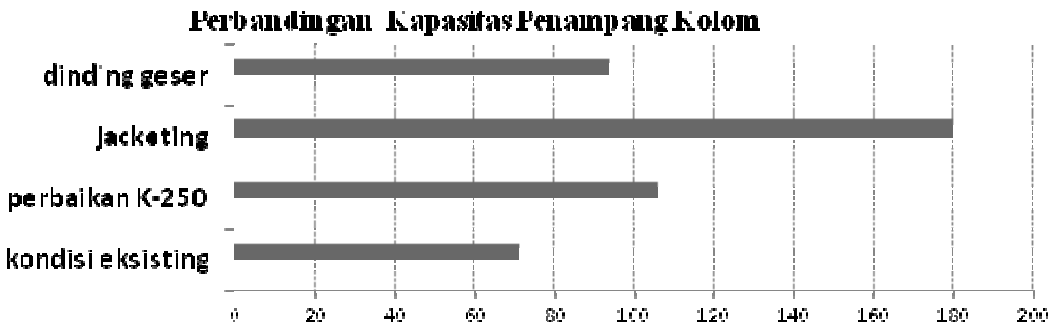

$(k N)$

Gambar 26. Perbandingan Kapasitas Penampang Kolon Ketiga Metoda Dengan Kondisi Eksisting

Dari Gambar 26. dapat dilihat bahwa baik metoda perbaikan dan metoda perkuatan dengan jacketing dapat meningkatkan kapasitas penampang kolom dengan nilai yang paling besar yaitu dua kali lipat dari kapasitas kolom sebelum jacketing. Metoda perbaikan meningkatkan kapasitas penampang kolom sebesar 48\% dari kapasitas kolom yang tidak diperbaiki, sedangkan peningkatan kapasitas penampang kolom dengan metoda dinding geser adalah sebesar 32\% dari kapasitas kolom kondisi eksisting.

\subsubsection{Perbandingan Gaya Aksial antara Kondisi Eksisting dengan Perbaikan dan Perkuatan}

Gambar 27. memperlihatkan perbandingan gaya aksial yang dialami struktur pada masing masing kondisi. Peningkatan gaya aksial terbesar dialami setelah dilakukan perkuatan dengan jacketing yaitu sebesar 18 \% dari gaya geser kolom yang tanpa jacketing. Hal ini membuktikan bahwa jacketing efektif untuk meningkatkan gaya aksial.

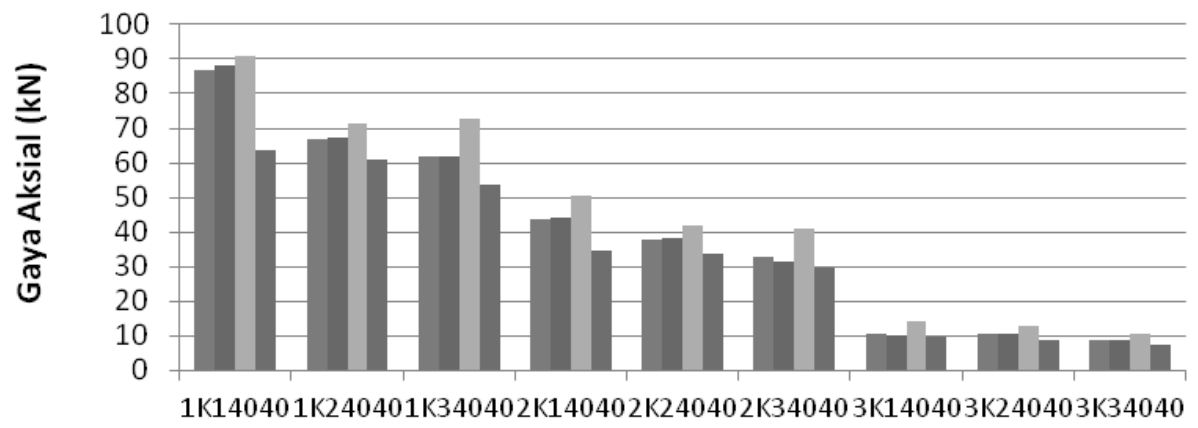

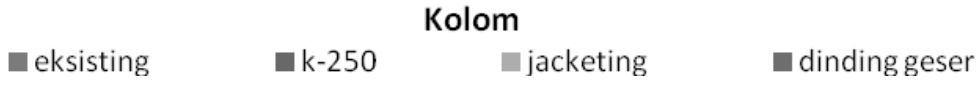

\section{Gambar 27. Perbandingan Gaya Aksial Maksimum antara Ketiga Metoda dengan Kondisi Eksisting}

\subsection{Resume Metoda Perbaikan dan Perkuatan}

Tabel 6. memperlihatkan perbaikan dan perkuatan yang dilakukan dibandingkan dengan kondisi awal serta peningkatan kapasitas darimasing-masing perbaikan dan perkuatan yang dilakukan. Dari tabel tersebut terlihat bahwa peningkatan kapasitas terbesar diperoleh dengan menggunakan 
metoda jacketing sedangkan penurunan displacement yang paling besar diperoleh dengan menggunakan metoda dinding geser.

Tabel 6. Resume Dan Perbandingan Kondisi Eksisting dengan Metoda Perbaikan dan Perkuatan

\begin{tabular}{|c|c|c|c|c|c|c|}
\hline \multirow{3}{*}{ No. } & \multirow{3}{*}{\multicolumn{2}{|c|}{ Identifikasi }} & \multirow{3}{*}{ Eksisting } & \multicolumn{3}{|c|}{ Alternatif } \\
\hline & & & & \multirow[b]{2}{*}{ Perbaikan } & \multicolumn{2}{|c|}{ Perkuatan } \\
\hline & & & & & Jacketing & $\begin{array}{c}\text { Dinding } \\
\text { Geser }\end{array}$ \\
\hline 1 & Mutubeton & & $\begin{array}{l}\text { Dibawahstandar } \\
\text { K-100 }\end{array}$ & $\mathrm{K}-250$ & $\mathrm{~K}-250$ & K-250 \\
\hline \multirow[b]{2}{*}{2} & & utama & $8 \varnothing 22$ & $8 \varnothing 22$ & $16 \varnothing 22$ & $8 \varnothing 22$ \\
\hline & Tulangan & sengkang & $\begin{array}{l}\text { Diameter }<(\varnothing 6 \mathrm{~mm}) \\
\text { Jaraksengkangjarang } \\
(20 \mathrm{~cm})\end{array}$ & $\begin{array}{l}\text { Ø10mm } \\
\text { Jaraksengkang } \\
10-15 \mathrm{~cm}\end{array}$ & $\begin{array}{l}\text { Ø12mm } \\
\text { Jaraksengkang } \\
10 \mathrm{~cm}\end{array}$ & $\begin{array}{l}\text { Ø10mm } \\
\text { Jaraksengkang } \\
10-15 \mathrm{~cm}\end{array}$ \\
\hline 3 & \multicolumn{2}{|c|}{ KapasitasPenampangKolom } & $71,198 \mathrm{kN}$ & $105,739 \mathrm{kN}$ & $179,8 \mathrm{kN}$ & $94,225 \mathrm{kN}$ \\
\hline 4 & \multicolumn{2}{|c|}{ Perpindahan } & $0,0151 \mathrm{~mm}$ & $0,106 \mathrm{~mm}$ & $0,01042 \mathrm{~mm}$ & $0,00046 \mathrm{~mm}$ \\
\hline
\end{tabular}

\section{KESIMPULAN}

Dari hasil analisa kegagalan struktur dan rekomendasi perkuatan dari Struktur Gedung Poltekes Siteba Padang diperoleh kesimpulan sebagai berikut:

1. Berdasarkan hasil hitungan struktur diketahui bahwa penyebab utama dari kerusakan struktur pada gedung Poltekes Siteba Padang adalah kurangnya kemampuan kolom dalam menahan gaya geser yang terjadi akibat jarak tulangan yang jarang dan diameter tulangan yang terlalu kecil, serta ditambah dengan rendahnya mutu beton yang digunakan.

2. Daerah disekitar gedung Poltekes merupakan daerah yang mempunyai potensi likuifaksi, akan tetapi tidak terdapat penurunan pondasi pada struktur bangunan gedung Poltekes Siteba Padang sehingga pondasi masih dapat dipergunakan kembali tanpa harus melakukan perbaikan.

3. Metoda perbaikan dapat mengembalikan kekuatan struktur seperti semula. Pada gedung Poltekes dilakukan dengan mengganti mutu beton menjadi K-250 dan menambah tulangan geser. Metoda ini meningkatkan kapasitas penampang kolom sebesar $48 \%$ dari kapasitas kolom tanpa perbaikan.

4. Perkuatan dengan metoda jacketing efektif untuk meningkatkan kekuatan geser kolom dan aksial kolom meskipun kurang efektif untuk meningkatkan kekuatan lentur kolom. Kekuatan geser kolom meningkat sebesar $10 \%$ dari geser kolom tanpa jacketing dan aksial kolom meningkat sebesar 18\% dari geser kolom tanpa jacketing. Kapasitas penampang kolom menangalami peningkatan yang cukup besar yaitu dua kali lipat dari kapasitas kolom sebelum jacketing.

5. Perkuatan dengan metoda perkuatan dinding geser pada gedung ini hanya menyelesaikan masalah pada lentur saja dengan kenaikan kapasitas kolom sebesar 32\% dari momen struktur tanpa dinding geser. Sementara untuk kegagalan geser harus tetap memberikan penambahan tulangan kembali.

\section{DAFTAR KEPUSTAKAAN}

Boen, Teddy dan Rekan, (2009), “Cara Memperbaiki Bangunan Sederhana yang Rusak Akibat Gempa Bumi.”, Jakarta. 
SNI 03-1726-2002, (2002), "Standar Perencanaan Ketahanan Gempauntuk Struktur Bangunan Gedung”, Badan Standarisasi Nasional, Puslitbang Pemukiman, Bandung.

SNI 03-2847-2002, (2002), “Tata cara Perhitungan Struktur Betonuntuk Bangunan Gedung”, Badan Standarisasi Nasional, Puslitbang Pemukiman, Bandung.

\section{J URNAL REKAYASA SIPIL}

